\title{
No-Tillage, Agropastoral and Agrosilvipastoral Systems
}

\author{
Wander Luis Barbosa Borges* \\ São Paulo Agribusiness Technology Agency, Brazil \\ Received: 阱July 17, 2018; Published: 阱 July 31, 2018 \\ *Corresponding author: Wander Luis Barbosa Borges, São Paulo Agribusiness Technology Agency, Brazil
}

\section{Mini Review}

According to the ONU (2016), the world population expected to reach 8.5 billion in the year 2030, 9.7 billion in 2050 and exceed 11 billion in 2100; and, according to FAO [1], the fast population growth, climate change and the degradation of water and land resources should make the world vulnerable to food insecurity, risking not be able to feed the entire population by 2050, and in order to set back the hunger and food insecurity, food production would need to grow at a higher level than the population, and this should to occur mainly in the areas already used for agriculture, with more intensive and sustainable use of land and water. A production system is considered sustainable when all the steps of the process meet social fare, economically viable and environmentally adequate processes [2]. Among them, are the no-tillage system, the agropastoral system and agrosilvipastoral system. The notillage system is considered the most sustainable and efficient management for soil conservation, due to all the benefits promoted by its chemical, physical and biological characteristics, such as the reduction of the direct impact of the rain drops, the increasing of water infiltration, the decreasing of superficial runoff, the reduction of thermic amplitude and the management of moisture, the reduction of weeds infestation, the increasing of organic matter content, the expansion of the "sowing window", the reduction of fuel consumption and nutrient cycling, among other advantages [3].

Due to all those advantages, the no-tillage system is recommended whenever is possible, once it is an example of sustainable production system, with environmental, social and economic benefits to all society, by: the mitigation of gases from the greenhouse effect, with carbon accumulation in the soil and the reduction of $\mathrm{CO} 2$ emission, since it needs less agricultural processes, when compared to the conventional tillage system; improvement of water quality and the reduction of soil loss and, by the increasing of crop yield and diversification of products, improving the profitability of the property and encouraging the management of the agriculturist in the field [4]. However, to obtain these results, is necessary to obey three basic principles required by no-tillage system: absence of preparation (no soil disturbance), crop rotation and permanent soil cover (straw) [3]. Unfortunately, in most part of the areas with the no-tillage system in Brazil, not all of these practices are adopted, and only vegetal residues from previous crops and weeds are use as straw, which, according to Stone [5], normally are insufficient for the whole soil cover, due to the high temperatures associated to the adequate moisture, in the tropics, that promote their rapid decomposition. This reinforces the concern of producing vegetable's residues with lower decomposition, which would lead the residue to protect the soil for a longer period [6].

For this reason, the follow of soil during autumn/winter and spring/summer is not recommended, being necessary, most of the time, to use crops aiming the formation of straw for the system, the so-called cover crops. The cover crops must present a rapid initial development and elevated yield of phytomass and may be used for grain production, seeds or fodder, bringing, besides the benefits of soil cover management, an extra recipe to justify its adoption by producers [3]. The agrosilvipastoral systems can be an advantageous alternative for farmers once it opens an opportunity for the diversification of economic activities in the property, especially with the insertion of the forest components that may generate an extra income to the producer like wood or energy, and, at the same time, it would create a favorable micro climate for pasture, that would keep it green for longer period in the off-season and would propitiate conditions of animal welfare [7]. These systems propitiate reciprocal benefits by recovering or reducing the causes of physical, chemical or biological degradation of the soil, resulting from each exploration. From the sustainability point of view, the benefits of these systems may be summarized as: a) Agronomics - by means of recovery and management of the productive soil characteristics; b) Economics - by means of diversification of offer and obtention of higher yield at lower costs with superior quality; c) Ecological - by means of reduction of erosion and of the dangerous biota to the cultivated species, with a consequent reduction of need for agricultural defensives; d) Socials 
- by means of dilution of profits, once the lifestock and agricultural activities concentrate and distribute the profits, respectively. The major generation of taxes, direct and indirect jobs, besides the settling of the man in the field must also be consider $[8,9]$.

\section{References}

1. Food and Agriculture Organization (FAO) (2016) Food may be lacking to supply the world's population by 2050 .

2. Freire J (2015) Sustainable Technology: Sustainable Production Systems.

3. Borges WLB (2015) Coverage Plants for Lavender Plants Paulista. A Granja pp. 5961.

4. Borges WLB (2012) The importance of straw. A Granja pp .67-69.

5. Stone LF, Silveira PM, Moreira JAA, Braz AJBP (2006) Evapotranspiration of irrigated common bean under no-tillage on different cover crop mulches. Brazilian Agricultural Research 41(4): 577-582.

6. Ceretta CA, Basso CJ, Herbes MG, Poletto NC, Silveira MJ (2002) Phytomass production and decomposition of winter cover crops and corn, under different management of nitrogen fertilization. Ciência Rural 32(1): 49-54.

7. Trecenti R, Oliveira MC, Hass G (2008) Grain-Livestock-Forestry Integration. Brasília: MAPA/SDC. pp. 54.

8. Kluthcouski J, Cobucci T, Aidar H, Yokoyama LP, Oliveira IP, et al. (2000) Santa Fe System-Embrapa Technology: crop-livestock integration by the consortium of annual crops with forages, in crop areas, in the direct and conventional systems. Santo Antônio de Goiás: Embrapa Rice and Beans. pp. 28.

9. United Nations (UN) (2016) UN projects world population to reach 8.5 billion by 2030 .

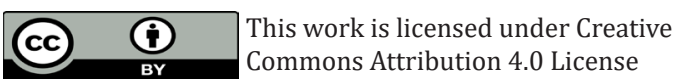

To Submit Your Article Click Here: Submit Article

DOI: $10.32474 /$ CIACR.2018.04.000177

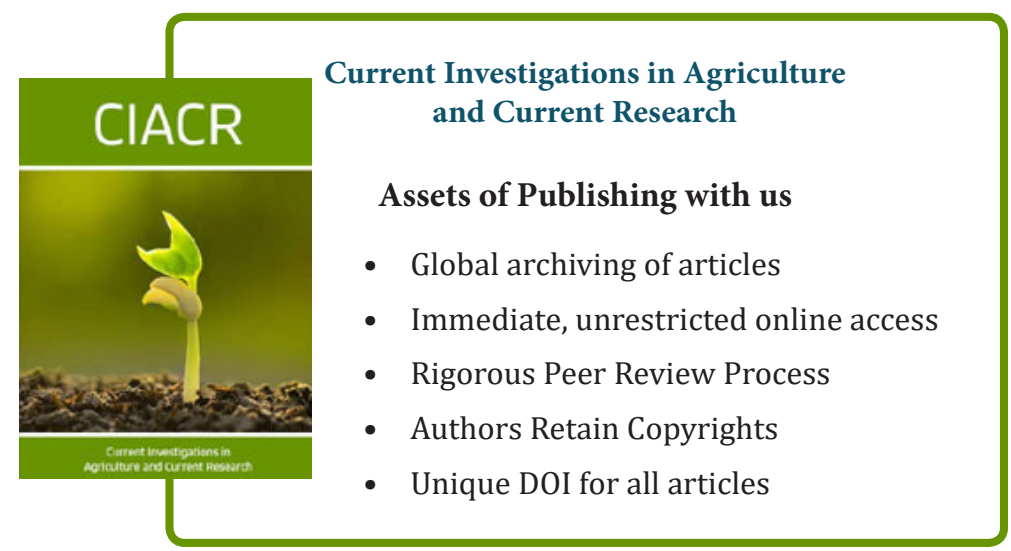

